\title{
TEKNIK PCR ITS RFLP UNTUK SELEKSI ISOLAT JAMUR PADA PENGUJIAN AGEN PENGENDALI HAYATI PADA SERANGAN GANODERMA TANAMAN Acacia mangium
}

\author{
PCR ITS-RFLP technique for selection of fungal isolates in biological control agent test \\ against Ganoderma attack in Acacia mangium plantation
}

Istiana Prihatini', Farah Aulya Faradilla ${ }^{2}$, dan Suranto ${ }^{2}$

${ }^{1}$ Kontributor Utama, Balai Bes ar Penelitian dan Pengembangan Bioteknologi dan Pemuliaan Tanaman Hutan Jl. Palag an Tentara Pelajar KM 15, Purwobinangun, Pakem, Sleman, Yogyakarta, Indonesia email: istiana.prihatini@biotifor.or.id

${ }^{2}$ Kontributor Utama, Universitas Sebelas Maret

Jl. Ir. Sutami No.36 A, Pucangs awit, Kec. Jebres, Kota Surakarta, Jawa Tengah, I

Tanggal diterima: 15 Februari 2019, Tanggal direvisi: 23 Februari 2019, Disetujui terbit: 17 Juni 2019

\begin{abstract}
In vivo control activities test of BCA candidate is required to evaluate its effectiveness. This test involved identification of the fungal species that inhabited the experimental plant after inoculation of BCA and pathogen. Identification of inhabitant fungi in the BCA control activity test can be conducted by culturing the fungi on artificial media. Fungal species can be identified based on morphological characters or genetic characters offungal culture. This study was conducted to determine the potential of PCR ITS-RFLP molecular markers in the initial selection process offungal isolates before identification based on DNA sequences and to select the enzyme that produce polymorphic PCR ITS RFLP pattern. Three enzymes (DraI, EcoRI and HinfI) were successfully separated 8 fungal cultures used in this studyinto three groups based on the pattern of PCR ITS DNA, while five other enzymes (BamHI, BclI HaeII, HpaI, and HindIII) were failed to cut the DNA ITS fragments, except for one isolate.
\end{abstract}

Keywords: fungal identification, isolates selection, restriction enzyme

\begin{abstract}
ABSTRAK
Pengujian aktivitas pengendalian kandidat APH secara in vivo diperlukan untuk mengetahui efektifitasnya. Pengujian ini memerlukan identifikasijenis jamur yang ditemukan pada organ tanaman uji. Salah satu metode yang dipakai untukidentifikasi jenis jamur pada uji aktifitas pengendalian APH yaitu melalui pembuatan kultur pada media buatan. Identifikasi jenis jamur dapat dilakukan berdasarkan karakter morfologi ataupun karakter genetik dari kultur jamur atau dengan marka DNA. Penelitian ini dilakukan untuk mengetah ui potensi marka molekuler PCR ITS-RFLP dalam proses seleksi awal isolat jamur sebelum dilakukan identifikasi berdas arkan sekuens DNA dan untuk memilih enzim restriksi yang memproduksi pola PCR ITS RFLP yang polimorfik. Tiga enzim restriksi (DraI, EcoRI dan Hinfl) dapat memisahkan 8 is olat jamur yang digunakan dalam penelitian ini menjadi tiga kelompok sesuai dengan profil PCR ITS DNA, sedangkan 5 enzim yang lain (BamHI, BclI, HaeII, HpaI, dan HindIII) tidak dapat memotong fragmen DNA ITS, kecuali pada satu isolat jamur saja.
\end{abstract}

Kata kunci: identifikasi jamur, seleksi isolate, enzim restriksi

\section{PENDAHULUAN}

Penelitian mengenai keragaman dan identifikasi jenis-jenis jamur semakin banyak dilakukan untuk berbagai keperluan, misalnya untuk mencari bahan alternatif obat, mencari mikroorganisme untuk membersihkan polusi pada tanah (Lawrence et al., 2018), mendeteksi patogen pada tanaman (Kowalski \& Drozynska, 2011; Nusaibah, Latiffah, \& Hassaan, 2011; Prihatini, Glen, Wardlaw, \& Mohammed,
2015), dan untuk mencari agen pengendali hayati pada tanaman pertanian (Xiang et al., 2016) maupun tanaman hutan (Puspitasari et al., 2016). Keragaman jenis jamur juga banyak dipelajari dari berbagai habitat alami yang berbeda misalnya dari tanah (Lawrence et al., 2018), dari air (Diguta, Proca, Jurcoane, \& Matei, 2018), manusia dan hewan (O'Donnell et al., 2010) serta tanaman dari berbagai organ 
yang berbeda (Harsono, Rakhmawati, \& Prihatini, 2016). Pendekatan yang dipakai pada penelitian mengenai keragaman jenis jamur dapat menggunakan metode culture-dependent yaitu melalui pembuatan kultur jamur atau pemindahan jamur-jamur pada media buatan (Tigini, Prigione, Di Toro, Fava, \& Varese, 2009), metode tanpa melalui pembuatan kultur jamur (culture-indepedent) (Pei, Chen, \& Kress, 2017) dan menggunakan gabungan dari kedua metode tersebut (Prihatini, Glen, Wardlaw, \& Mohammed, 2016).

Salah satu gangguan serius pada tanaman kehutanan di Indonesia adalah serangan hama dan penyakit, misalnya penyalit karat tumor dan boktor pada sengon (Endang \& Farikhah, 2010; Putri \& Bramasto, 2017) dan penyakit busuk akar pada Acacia mangium yang disebabkan oleh beberapa jenis Ganoderma (Glen et al., 2009; Old, Lee, Sharma, \& Zi, 2000). Salah satu upaya pengendalian jamur patogen pada tanaman kehutanan yang dikembangkan saat ini adalah penggunaan agen pengendali hayati (APH) misalnya pada penyakit busuk akar (Agustini, Wahyuno, Indrayadi, \& Glen, 2014; Puspitasari et al., 2016). Potensi atau efektifitas APH dalam pengendalian hama dan penyakit dapat diketahui dengan melakukan pengujian aktivitas pengendalian patogen (Buana, Wahyudi, \& Toruan-Mathius, 2014; Elad, Baker, \& Faull, 2004). Pengujian aktivitas pengendalian dari kandidat APH secara in vivo akan memerlukan deteksi dan konfirmasi ulang jenis patogen dan kandidat APH pada organ tanaman yang diuji serta melibatkan jumlah sampel yang besar. Deteksi dan konfirmasi ulang dapat dilakukan dengan metode culturedependent (Elad et al., 2004), menggunakan metode deteksi secara langsung melalui penggunaan penanda DNA spesifik jenis atau species specific primer (Prihatini, Rimbawanto, Puspitasari, \& Fauzi, 2018), maupun menggunakan keduanya (Buana et al., 2014). Penggunaan penanda DNA spesifik jenis memerlukan pengembangan penanda spesifik terlebih dahulu dan terbatas pada jenis-jenis yang diinginkan saja (Yuskianti et al., 2014). Adapun metode culture-dependent akan memberikan kelebihan dengan didapatkannya isolat jamur-jamur lain selain patogen dan kandidat APH yang mungkin memberikan pengaruh dalam aktifitas pengendalian hama dari APH (Elad et al., 2004), namun kekurangan dari metode ini adalah jumlah isolat yang dihasilkan cukup banyak dan memerlukan identifikasi jenis dari setiap isolat.

Karakter morfologi isolat dapat dilakukan untuk mengenali jenis jamur (Puspitasari et al., 2016), namun pengamatan ini terbatas pada jenis jamur tertentu dan pada tingkat taksonomi tertentu (Duttw eiler, Sun, Batzer, Harrington, \& Gleason, 2008; Nusaibah et al., 2011), sehingga konfirmasi jenis berdasarkan karakter genetik (DNA) tetap diperlukan, terutama untuk jenisjenis yang memiliki kemiripan bentuk isolat (Prihatini, Glen, Wardlaw, \& Mohammed, 2014; Yuskianti et al., 2014). Penanda genetik juga dapat mempersingkat waktu dan tenaga yang diperlukan dalam identifikasi jenis jamur (Diguta, Vincent, Guilloux-Benatier, Alexandre, \& Rousseaux, 2011).

Pengelompokan jenis jamur atau seleksi isolat berdasarkan karakter genetik dapat dilakukan menggunakan metode PCR ITSRFLP (Diguta et al., 2011; Mohammed, 2013). Metode ini dimulai dari proses amplifikasi DNA dari daerah ITS (Internal Transcribed Spacer) menggunakan mesin PCR (Polymerase Chain Reaction) dan dilanjutkan dengan teknik metode (Restriction Fragment Length Polymorphism) untuk memotong amplikon ITS rDNA menggunakan enzim restriksi (Diguta et al., 2011; Duttweiler et al., 2008). Fragmen ITS banyak digunakan untuk identifikasi maupun karakterisasi jamur karena mudah diamplifikasi, terkonservasi, konsisten, serta memiliki variasi tinggi dalam satu genus, sehingga akan menghasilkan amplikon yang spesifik (Shamim et al., 2017). Pemotongan amplikon DNA ITS menggunakan enzim restriksi akan menghasilkan variasi potongan DNA yang berbeda pada sampel yang memiliki 
susunan DNA yang berbeda (Srivastava, Gupta, Lal, \& Sinha, 2017) dan sebaliknya akan menghasilkan pola yang sama pada sampel yang memiliki susunan DNA yang serupa (Viaud, Pasquier, \& Brygoo, 2000). Penggabungan dari kedua PCR ITS dan RFLP tersebut memungkinkan dihasilkannya penanda yang bersifat spesifik ditingkat spesies, dan memiliki polimorfisme yang tinggi pada isolat jamur tertentu misal Fusarium (Datta, Choudhary, Shamim, \& Dhar, 2011) dan Ganoderma (Nusaibah et al., 2011). Penanda ini juga terbukti murah, mudah digunakan dan tidak memerlukan waktu yang lama pada studi keragaman jenis jamur melalui proses isolasi jamur (Diguta et al., 2011), maupun tanpa melalui tahapan isolasi jamur (Viaud et al., 2000). Penelitian ini dilakukan untuk mengetahui potensi teknik PCR ITS-RFLP dalam seleksi isolat-isolat yang dihasilkan dari proses uji aktivitas pengendalian APH untuk identifikasi awal jamur belum diketahui jenisnya. Diharapkan penggunaan teknik tersebut dapat mengurangi biaya dan waktu yang diperlukan untuk identifikasi jenis dalam proses pengujian APH di lapangan.

\section{BAHAN DAN METODE}

\section{A. Waktu dan tempat}

Penelitian dilakukan di Laboratorium Genetika Molekular Balai Besar Penelitian dan Pengembangan Bioteknologi dan Pemuliaan Tanaman Hutan (B2PPBPTH) Yogyakarta pada tanggal 8 Januari sampai dengan 6 Februari 2018.

\section{B. Bahan dan alat penelitian}

Delapan isolat jamur yang diisolasi dari tunggul akar pohon Acacia mangium yang belum teridentifikasi jenisnya (Tabel 1) digunakan dalam penelitian ini. Delapan isolat jamur tersebut memiliki karakter morfologi isolat yang mirip (Tabel 1) dan tidak cukup memberikan informasi mengenai genus maupun jenis jamurnya.

\section{Ekstraksi dan pengenceran DNA}

Ekstraksi DNA dimulai dengan melakukan proses pelisisan sel menggunakan buffer SDS (Raeder \& Broda, 1985) yang telah dimodifikasi menggunakan metal beads dan mesin bead beater (Prihatini et al., 2018). Hasil ekstraksi berupa DNA murni dimasukkan didalam microtube ukuran $1,5 \mathrm{~mL}$ yang steril dan disimpan pada suhu 5oC sebelum digunakan pada proses PCR. Pada proses PCR digunakan konsentrasi DNA template yang berbeda dengan pengenceran berseri menggunakan larutan TE. Pengenceran DNA dimulai dari $10 \times$ pengenceran $(1 / 10), 20 \times(1 / 20)$ dan 40x (1/40). Penggunaan DNA template dengan tiga konsentrasi yang berbeda tersebut dimaksudkan sebagai ulangan pada proses PCR ITS dan juga pada proses RFLP.

\section{PCR ITS}

Proses PCR dilakukan terhadap delapan sampel dengan masing-masing tiga ulangan untuk mengamplifikasi daerah ITS. Adapun primer yang digunakan adalah ITS1F dengan urutan sekuen 5'CTT GGT CAT TTA GAG GAA GTA A'3 (Gardes \& Bruns, 1993) sebagai forward primer dan ITS4 sebagai reverse primer urutan sekuen 5'TCC TCC GCT TAT TGA TAT GC'3 (White, Bruns, Lee, \& Taylor, 1990).

Amplifikasi dilakukan menggunakan PCR master mix KAPA2G Fast PCR Kit (Kapa Biosystem) dengan konsentrasi akhir 1× PCR reaction buffer $\mathrm{A}, 0.2 \mathrm{mM}$ deoxynucleotide triphosphate (dNTPs), $1.5 \mathrm{mM} \mathrm{MgCl} 2$ dan $0.5 \mathrm{U}$ DNA polymerase kemudian pada master mix tersebut ditambahkan $0.5 \mu \mathrm{M}$ oligonucleotide primer (Genew orks) forward maupun reverse, dan air hingga volume menjadi $20 \mu \mathrm{L}$ per reaksi PCR sebelum ditambahkan DNA template sebanyak $5 \mu \mathrm{L}$. Amplifikasi PCR dilakukan menggunakan mesin GeneAmp ${ }^{\circledR}$ PCR System 9700 (Applied Biosystem) pada profil suhu sebagai berikut: $94^{\circ} \mathrm{C}$ selama 3 menit, diikuti dengan 35 siklus dari $94^{\circ} \mathrm{C}$ selama 30 detik, 
$55^{\circ} \mathrm{C}$ selama 30 detik dan $72^{\circ} \mathrm{C}$ selama 1 menit, serta ekstensi akhir pada suhu $72^{\circ} \mathrm{C}$ selama 7 .

Tabel 1. Isolat jamur dari tunggul akar Acacia mangium yang digunakan dalam seleksi karakter genetik mengunakan metode PCR ITS-RFLP

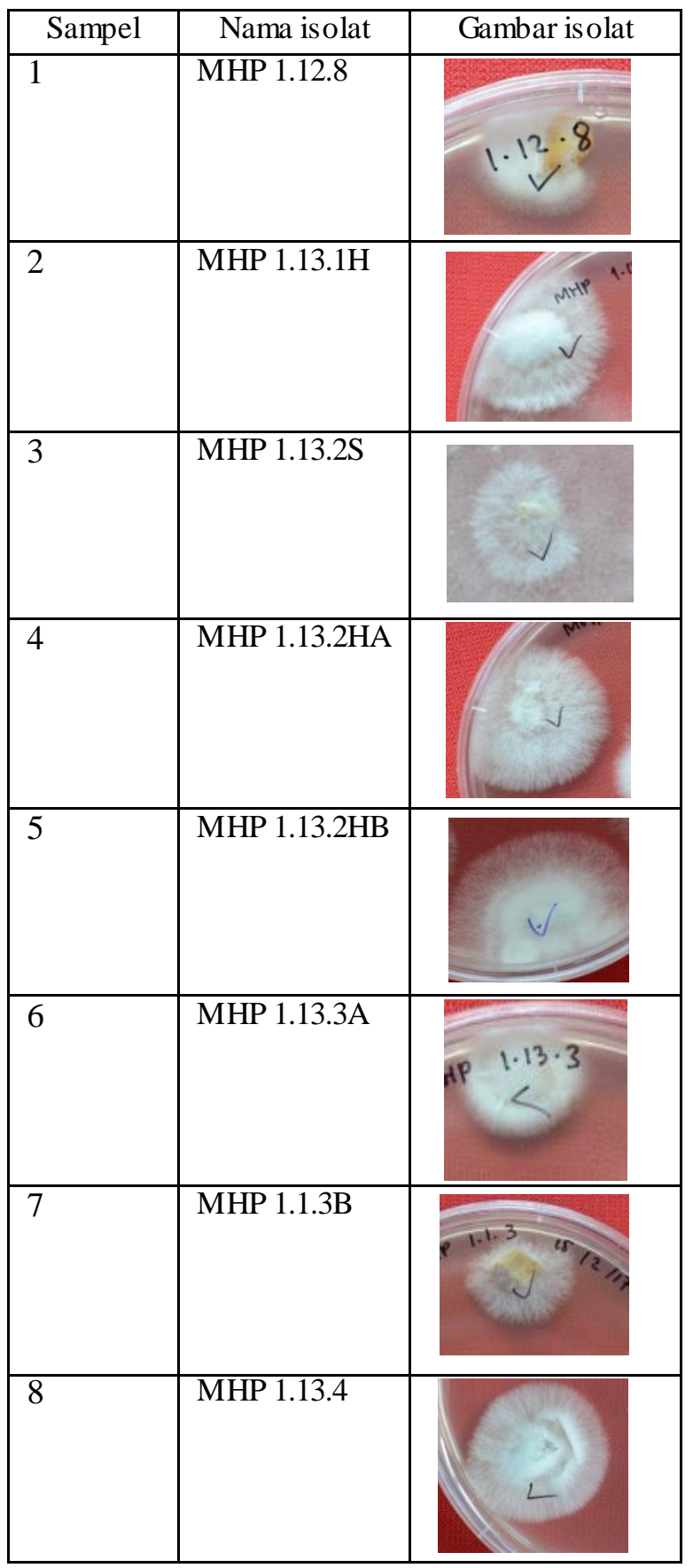

\section{E. Elektroforesis}

Elektroforesis untuk melihat adanya amplic on hasil PCR ITS dilakukan dengan mengunakan gel agarose 1\% dengan pewarna Ethidium bromide (EtBr) sebanyak $2,5 \mu \mathrm{L}$ per
$40 \mu \mathrm{L}$ larutan 1×TBE. Gel agarose kemudian dimasukkan ke dalam bak elektroforesis yang berisi $1 \times \mathrm{TBE}$ buffer dan pewarna $\mathrm{EtBr}$ sebanyak $200 \mu \mathrm{L}$ per 1L larutan. DNA Ladder 100bp (Vivantis) digunakan sebagai marker untuk memperkirakan ukuran DNA yang dihasilkan. Tangki elektroforesis diberi aliran listrik dengan tegangan sebesar 120 volt selama \pm 45 menit.

\section{F. RFLP}

Hasil amplifikasi PCR dipotong menggunakan 8 enzim restriksi yaitu EcoRI (BioLabs), BamHI, BclI, DraI, HaelI, HpaI HindIII dan HinfI (Boehringer Mannheim $\mathrm{GmbH})$. Reaksi RFLP terdiri dari 1x incubation buffer for restriction enzymes (BioLabs dan Boehringer Mannheim GmbH), $0,1 \mu \mathrm{g} / \mu \mathrm{L}$ BSA (BioLabs); 0,03-0,1 U enzim restriksi dan $5 \mu \mathrm{L}$ produk PCR (amplikon) dan ditambahkan air hingga volume menjadi $10 \mu \mathrm{L}$ per reaksi. Reaksi tersebut kemudian diinkubasi pada suhu $37 \mathrm{oC}$ selama 2 jam pada mesin GeneAmp® PCR System 9700. Hasil RFLP disimpan pada suhu $5 \mathrm{oC}$ sebelum dipisahkan pada proses elektroforesis menggunakan gel agarose 2\% yang diberi aliran listrik 100 Volt, selama 3 jam. Gel elektroforesis PCR juga diwarnai dengan $\mathrm{EtBr}$ dengan formula yang sama dengan elektroforesis terhadap hasil PCR ITS.

\section{G. Analisis Data}

Dari hasil visualisasi gel elektroforesis, diperoleh gambar pola fragmen DNA yang selanjutnya dimasukkan dalam tabel skoring yaitu dengan memberi skor angka 1 jika terdapat pita DNA pada ukuran panjang basa tertentu, diberi angka 0 jika pada ukuran tersebut tidak terdapat pita DNA. Hasil skoring ditulis dalam bentuk matriks (1 dan 0) dan dianalisa menggunakan aplikasi POPGEN ver 1.32 (Yeh, Yang, Boyle, Ye, \& Mao, 1999) untuk menyusun dendogram berdasarkan jarak genetiknya sesuai dengan pola fragmen yang dihasilkan dari PCR ITS-RFLP. 


\section{HASIL DAN PEMBAHASAN}

\section{A. Hasil}

\section{Amplifik asi PCR}

Hasil dari PCR menggunakan penanda molekuler (primer) ITS ditampilkan pada gambar 1. Pada isolat 1, 2, 4, 5 dan 6 dengan tiga ulangan berupa pengenceran yang berbeda $(10 \times, 20 \times, 40 \times)$ menghasilkan amplikon DNA yang berukuran $800 \mathrm{bp}$, pada isolat 3 menghasilnya amplikon berukuran sedikit lebih kecil (790 bp), sedangkan sampel 7 dan 8 pada semua ulangan menghasilkan amplikon yang berukuran lebih besar $(850 \mathrm{bp})$. Semua amplikon terlihat tebal dan jelas, hal ini menunjukkan bahwa daerah ITS dari DNA dari semua isolat jamur yang diteliti dapat teramplifikasi dengan baik.

\section{Fragment PCR ITS-RFLP}

Penggunaan enzim restriksi BamHI (gambar 2A) pada amplikon DNA dari isolat 1, 2, 4, 5, 6 menghasilkan satu fragmen berukuran $700 \mathrm{bp}$, sedangkan pada isolat 3 dihasilkan dua fragmen berukuran 690 dan 700 bp dan pada isolat 7 dan 8 dihasilkan satu fragmen yang berukuran 800 bp. Hasil yang sama terjadi pada semua ulangan yang dipakai.

Penggunaan enzim BclI (gambar 2B) menghasilkan satu fragmen berukuran $800 \mathrm{bp}$ pada semua ulangan dari isolat 7 dan 8 , serta satu fragmen berukuran 700 bp pada isolat 2, 4, 5 , dan 6. Pola pemotongan enzim restriksi yang terjadi pada isolat 1 berupa dua fragmen berukuran 800 bp dan 700 bp, sedangkan pada isolat 3 dihasilkan dua fragmen yang saling berdekatan yaitu berukuran 680 bp dan 690 bp. Pola yang sama dihasilkan oleh tiga ulangan dari isolat yang sama.

Pemotongan amplikon DNA menggunakan enzim restriksi DraI (gambar 2C) pada semua ulangan dari isolat 1 menghasilkan tiga fragmen berukuran $610 \mathrm{bp}, 700 \mathrm{bp}$ dan 800 bp. Tiga fragmen juga dihasilkan pada isolat 2 , 4,5 dari semua ulangan namun berbeda ukurannya yaitu 210 bp, 480 bp dan 700 bp, sedangkan pada isolat 3 berukuran $210 \mathrm{bp}, 480$ bp dan 690 bp. Pada semua ulangan dari isolat 6 terlihat adanya dua fragmen berukuran $610 \mathrm{bp}$ dan $700 \mathrm{bp}$, sedangkan pada isolat 7 dan 8 hanya terlihat satu fragmen berukuran $800 \mathrm{bp}$.

Hasil pemotongan amplikon DNA menggunakan enzim restriksi EcoRI (gambar 2D) menunjukan bahwa isolat 1 dan 6 terlihat adanya satu fragmen yang berukuran $700 \mathrm{bp}$. Isolat 2, 4, 5 memiliki pola hasil pemotongan yang sama dan menghasilkan dua fragmen yang berukuran $390 \mathrm{bp}$ dan $700 \mathrm{bp}$. Isolat 3 terpotong menjadi tiga fragmen berukuran $380 \mathrm{bp}, 520 \mathrm{bp}$ dan 690 bp. Adapun isolat 7 dan 8 memiliki pola pemotongan yang sama dan menghasilkan tiga fragmen yang berukuran $410 \mathrm{bp}, 430 \mathrm{bp}$ dan 800 bp.

Pemotongan amplikon menggunakan enzim restriksi HaeII (gambar 2E) menghasilkan dua fragmen pada isolat 1 dengan ukuran $700 \mathrm{bp}$ dan $800 \mathrm{bp}$, serta pada isolat 3 dengan ukuran $690 \mathrm{bp}$ dan $700 \mathrm{bp}$, sedangkan pada isolat 2, 4, 5, 6, semua ulangan hanya dihasilkan satu fragmen berukuran 700 bp dan ukuran 800 bp pada isolat 7 dan 8 .

Enzim restriksi HindIII menghasilkan pemotongan pada isolat 3 dengan munculnya dua fragmen yang berukuran 560 bp dan 700 bp (gambar 2F). Enzim restriksi ini hanya menghasilkan satu fragmen pada isolat yang lain, yaitu fragmen berukuran 700 bp pada isolat $1,2,4,5,6$ dan ukuran 800 bp pada isolat 7 dan 8 .

Pemotongan amplikon DNA dengan enzim restriksi Hinf $\mathrm{I}$ (gambar 2G) menghasilkan dua fragmen yang berukuran 700 bp dan 800 ada isolat 1, ukuran 680 bp dan 690 bp pada isolat 3, dan menghasilkan satu fragmen berukuran 700 bp pada isolat 2, 4, 5 dan ukuran fragmen 800 bp pada isolat 7 dan 8 . Adapun penggunaan enzim restriksi $\mathrm{HpaI}$ (gambar $2 \mathrm{H}$ ) hanya menghasilkan satu fragmen saja, pada semua isolat dan semua ulangan yang dipakai dalam penelitian ini. 


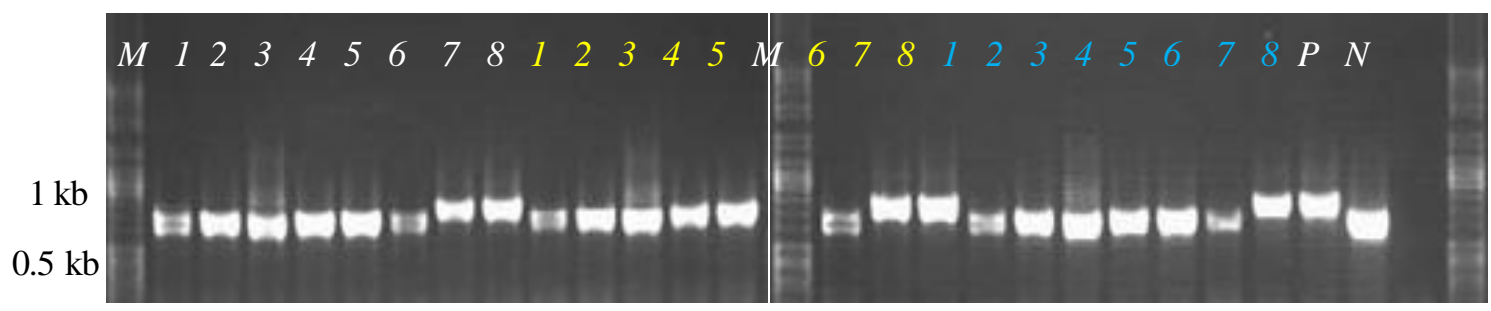

Gambar 1. Fragmen rDNA ITS 8 isolat jamur dari3 konsentrasi DNA yang berbeda. Keterangan: Nomor 18 menunjukkan nomor isolat jamur yang berbeda, nomor dengan warna putih adalah DNA dengan pengenceran 10x, warna kuning adalah DNA dengan pengenceran 20x, dan warna biru adalah DNA dengan pengenceran 40x. M adalah marker (100 bp Ladder), P adalah kontrol positif (DNA jamur) dan $\mathrm{N}$ adalah kontrol negatif (air).
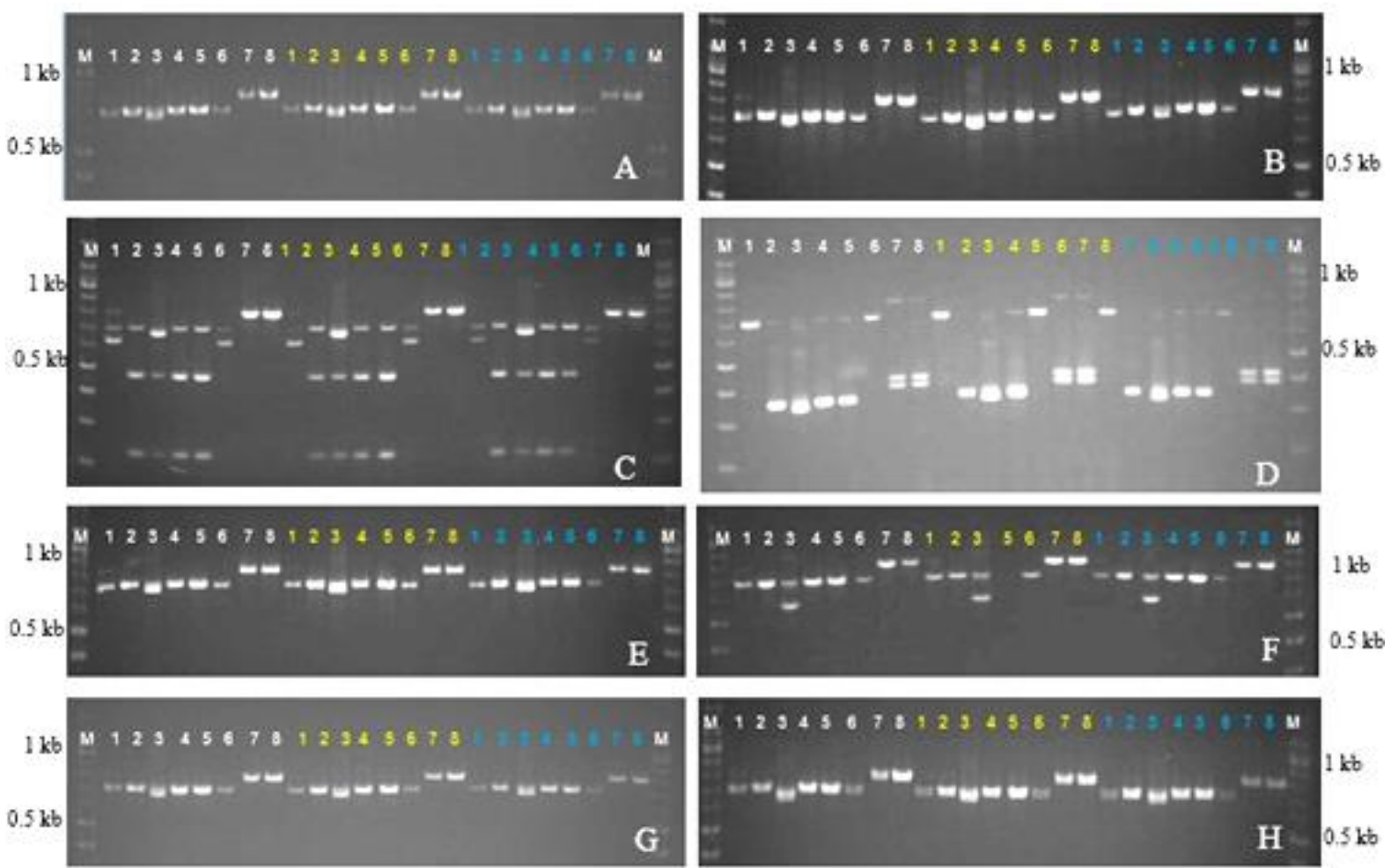

Gambar 2. Profile fragmen DNA ITS-RFLP dari 8 isolat jamur tunggul kayu Acacia mangium menggunakan 8 enzim restriksi BamHI(A), BclI(B), DraI (C), EcoRI(D), HaeII (E), HindIII (F), HinFI(G) dan HpaI $(\mathrm{H})$. Keterangan : Nomor 1-8 isolat DNA sampel no 1-8, warna putih adalah sampel DNA dengan pengenceran $1 / 10$, warna kuning adalah sampel dengan pengenceran $1 / 20$, dan warna biru adalah sampel dengan pengenceran 40x. M adalah marker (100 bp Ladder).

\section{Dendogram}

Dendogram disusun berdasakan pola pita DNA ITS yang telah dipotong menggunakan 8 enzim restriksi digunakan untuk melihat hubungan antara 8 isolat yang digunakan dalam penelitian ini (Gambar 3). Pada dendogram tersebut terlihat bahwa 8 isolat terbagi dalam 4 kelompok (klaster) yang berbeda. Isolat 1 dan 6 berada dalam 1 klaster yang sama meskipun terdapat memiliki variasi pola PCR ITS RFLP. Klaster kedua terdiri dari isolat 2, 4 dan 5 yang tidak memiliki perbedaan pola PCR ITS RFLP, adapun klaster ketiga hanya ditempati oleh isolat 3, yang menunjukkan bahwa profil PCR ITS RFLP isolat ini berbeda dari 7 isolat yang lain. Adapun klaster keempat ditempati oleh isolat 7 dan 8 , yang memiliki profil PCR ITS RFLP yang sama.

\section{B. Pembahasan}

Penelitian ini berhasil menunjukkan adanya variasi profil PCR ITS RFLP antar 8 


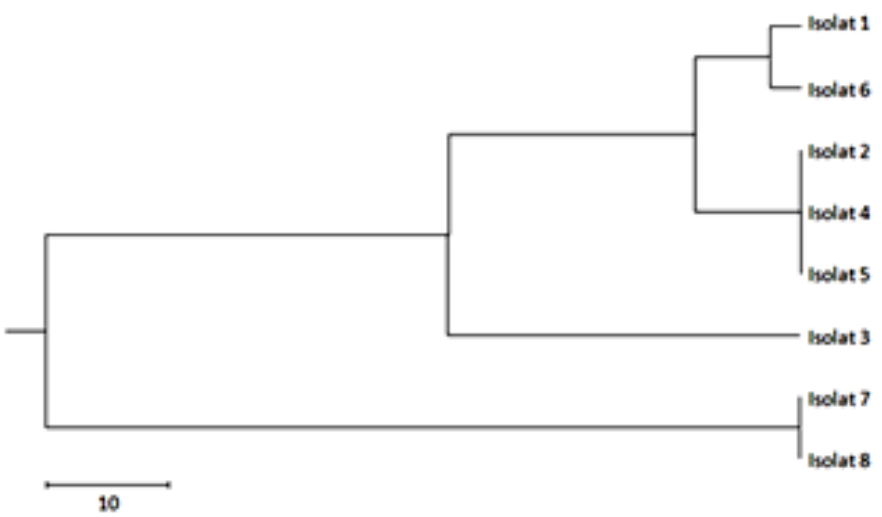

Gambar 3. Dendogramhubung an kekerabatan 8 is olat jamur tunggul kayu Acacia mangium yang disusun berdasarkan profile fragmen DNA ITS-RFLP dengan 3 ulangan. Pemotongan amplikon DNA ITS menggunakan 8 enzim restriksi BamHI, BclI, DraI, EcoRI, HaeII, HpaI, HindII dan HinFI. Tanda baris (bar) menunjukkan besarnya perbedaan pola fragmen DNA an tar isolat.

isolat jamur yang memiliki kemiripan karakter morfologi. Hasil analisa menunjukkan 8 isolat tersebut dapat dipisahkan ke dalam lima kelompok berdasarkan profil PCR ITS RFLP. Penelitian serupa pada jamur endofit tebu, menemukan bahwa tiga jenis jamur yang berbeda memiliki profil PCR ITS RFLP yang berbeda, sedangkan isolat yang berbeda dari jenis jamur sama memiliki sedikit variasi profil PCR ITS RFLP (Srivastava et al., 2017). Penelitian lain pada buah anggur mendapatkan 42 profil PCR ITS RFLP dari 43 jenis jamur yang diamati dan hanya 2 jenis jamur dari genus Penicillium yang memiliki profil sama (Diguta et al., 2011).

Pemilihan jenis dan jumlah enzim restriksi pada penggunaan metode PCR ITS RFLP berpengaruh terhadap tingkat diskriminasi atau pembedaan jenis jamur. Penelitian ini juga menunjukkan bahwa tidak semua enzim restriksi dapat digunakan untuk membedakan 8 isolat jamur yang diamati. Hal ini dikarenakan enzim restriksi akan mengenali sekuens nukleotida yang spesifik spesifik (restriction site) dan melakukan pemotongan pada sekuens tersebut (Gherbawy and Voigt, 2010). Berdasarkan hasil yang diperoleh, dapat dikatakan bahwa hanya tiga dari 8 enzim restriksi yang dipakai dalam penelitian ini yang efektif atau memberikan variasi (polimorphism) yang tinggi yaitu adalah DraI, EcoRI dan HinfI. Enzim restriksi HpaI menunjukkan adanya pemotongan amplikon ITS pada satu isolat jamur namun dua fragmen yang dihasilkan berukuran hampir sama sehingga terlihat seperti hanya ada 1 fragmen. Sementara itu enzim restriksi BamHI, BclI HaelI dan HindIII tidak memberikan variasi dalam profil PCR ITS RFLP terhadap 8 isolat.

Pemotongan amplikon ITS menggunakan enzim restriksi DraI pada penelitian ini memberikan variasi fragmen yang paling tinggi yaitu dengan menghasilkan lima profil PCR ITS RFLP yang berbeda dari 8 isolat yang digunakan. Enzim restriksi ini juga berhasil digunakan pada identifikasi jenis jamur Flammulina velutipes bersama beberapa enzim lain yaitu FokI, HaeII, MboII, dan NlaIV (Palapala, Aimi, Inatomi, \& Morinaga, 2002). Penggunaan DraI bersama beberapa enzim yang lain juga terbukti mampu memberikan variasi profil pemotongan dalam identifikasi jenis jamur dengan beberapa metode yang berbeda, misalnya PCR IGS RFLP pada Alternaria spp (Hong, Liu, \& Pryor, 2005) dan tRFLP pada jamur Candida spp (Szemiako, Śledzińska, \& Krawczyk, 2017). Penggunaan enzim ini secara tunggal dengan metode PCR ITS RLFP mampu membedakan dua kelompok jamur Anaeromyces mucronatus yang memiliki aktifitas enzim hidrolitik berbeda (Fliegerová, Paîoutová, Mrázek, \& Kopeân, 2002).

Enzim restriksi EcoRI dan HinfI juga memberikan variasi pemotongan yang tinggi 
misalnya pada identifikasi jenis Stachybotrys, Penicillium, Aspergillus and Cladosporium (Dean, Kohan, Betancourt, \& Menetrez, 2005; Mohammed, 2013). Pada studi yang lain, enzim restriksi HinfI juga terbukti mampu memberikan 8 profil pemotongan yang berbeda terhadap 23 jenis jamur dari genus Penicillium dan Aspergillus (Diguta et al., 2018).

Adapun jumlah enzim restriksi yang dipakai pada identifikasi atau diferensiasi isolat jamur menggunakan metode PCR ITS RFLP bervariasi mulai dari satu hingga lebih dari lima enzim restriksi tergantung dari tujuan dan kelompok jenis jamur yang dipelajari. Penggunaan satu hingga tiga enzim restriksi biasanya digunakan untuk membedakan kelompok jamur yang sudah diketahui spesies atau genusnya. Penggunaan satu enzim pada jenis jamur Anaeromyces mucronatus dapat membedakan dua kelompok jamur yang memiliki aktifitas enzim hidrolitik berbeda (Fliegerová et al., 2002). Profil PCR ITS RFLP yang dihasilkan dari satu enzim juga terbukti mampu membedakan beberapa genus jamur yang menyebabkan penyakit pada apel (Duttweiler et al., 2008). Pada penelitian terhadap genus Aspergillus dan Penicillium penggunaan dua enzim mampu membedakan tujuh jenis yang berbeda, sedangkan untuk membedakan tiga jenis Ganoderma yang diisolasi dari tiga inang yang berbeda diperlukan tiga enzim restriksi (Nusaibah et al., 2011). Penggunaan empat jenis enzim atau lebih biasanya digunakan dalam identifikasi jenisjenis jamur dalam studi komunitas jamur (Diguta et al., 2018, 2011).

Pada dendogram yang disusun berdasarkan lima profil PCR ITS RFLP yang berbeda, delapan isolat jamur yang diamati pada penelitian ini dibagi ke dalam 3 klaster atau kelompok dan diasumsikan setiap klaster pada dendogram tersebut memiliki susunan DNAITS yang sama atau mirip. Kelompok pertama yaitu isolat 1 dan 6 yang memiliki profil PCR ITS RFLP berbeda, namun memiliki banyak kemiripan. Perbedaan hanya ditunjukkan oleh adanya tiga fragmen yang berbeda yang dihasilkan oleh tiga enzim yaitu DraI, HaeII dan BclI. Kedua isolat tersebut diduga merupakan jenis jamur yang berbeda namun memiliki kedekatan hubungan dengan adanya kemungkinan miripnya struktur sekuen ITS antara kedua isolat.

Kelompok kedua terdiri dari isolat 2, 4, dan 5. Ketiga isolat tersebut tidak memiliki variasi profil PCR ITS RFLP, sehingga dapat diasumsikan bahwa ketiganya memiliki struktur DNA ITS yang sama dan mungkin merupakan jenis jamur yang sama. Kelompok ketiga terdiri dari isolat 7 dan 8 yang memiliki profil PCR ITS RFLP sama dan diasumsikan memiliki struktur DNA ITS yang sama. Hal ini juga menunjukkan bahwa kemungkinan besar kedua isolat tersebut merupakan jenis jamur yang sama. Adapun isolat 3 tidak menempati klaster manapun dan terpisah dari isolat-isolat yang lain. Hal ini disebabkan oleh profil PCR ITS RFLP yang berbeda dan juga menunjukkan adanya perbedaan struktur DNA ITS dengan isolat lain.

Konsentrasi DNA yang berbeda yang digunakan sebagai ulangan pada penelitian ini, tidak menunjukkan hasil amplifikasi yang berbeda. Hasil ini berbeda dengan penelitian sebelumnya yang menemukan bahwa penggunaan DNA dengan pengenceran 20x memberikan hasil amplifikasi daerah ITS yang lebih baik daripada DNA dengan pengenceran 10x (Prihatini et al., 2018). Perbedaan hasil dari kedua penelitian ini mungkin disebabkan karena penggunaan DNA polymerase dan profil suhu yang berbeda dalam proses amplifikasi DNA ITS.

Identitas jenis jamur yang digunakan dalam penelitian ini tidak dapat diketahui dengan metode PCR ITS RLFP, sehingga perlu dilakukan menggunakan metode sekuensing DNA untuk membandingkan urutan DNA dari isolat-isolat yang diuji dengan database sekuen DNA jamur yang disimpan pada database umum misalnya Genbank (Clark, KarschMizrachi, Lipman, Ostell, \& Sayers, 2016) atau 
Unite (Nilsson et al., 2018). Profil PCR ITS RFLP yang dihasilkan oleh tiga enzim restriksi DraI, EcoRI dan HinfI diharapkan akan mampu membedakan jenis jamur dari isolat yang didapatkan dari hasil pengujian aktifitas pengendalian APH maupun pada penelitian keragaman jenis jamur yang menggunakan metode culture dependent.

\section{KESIMPULAN}

Penelitian ini menunjukkan bahwa enzim restriksi DraI, EcoRI dan HinfI mampu memberikan profil PCR ITS RLFP yang berbeda pada terhadap isolat jamur yang belum diketahui jenisnya dan memiliki karakter morfologi isolat yang mirip. Identifikasi jenis berdasarkan sekuen DNA masih diperlukan untuk menguji apakah profil PCR ITS RLFP yang dihasilkan oleh ketiga enzim tersebut sesuai dengan kelompok taksonominya.

\section{UCAPAN TERIMA KASIH}

Penelitian ini merupakan bagian dari penelitian yang dibiayai oleh anggaran DIPA tahun 2018. Sampel dan gambar isolat yang digunakan dalam tulisan ini disediakan oleh Desy Puspitasari dan merupakan bagian dari koleksi isolat dari penelitian ACIAR. Terimakasih kepada semua pihak yang telah membantu secara langsung maupun tidak langsung dalam kegiatan penelitian di laboratorium.

\section{DAFTAR PUSTAKA}

Agustini, L., Wahyuno, D., Indrayadi, H., \& Glen, M. (2014). In vitro interaction between Phlebiopsis sp. and Ganoderma philippii isolates. Forest Pathology, 44(6), 472-476. https ://doi.org/10.1111/efp.12143

Buana, R. F. N., Wahyudi, A. T., \& Toruan-Mathius, N. (2014). Control Activity of Potential Antifungal-Producing Burkholderia sp. in Suppressing Ganoderma boninense Growth in Oil Palm. Asian Journal of Agricultural Research, 8, 259-268.

Clark, K., Karsch-Mizrachi, I., Lipman, D. J., Ostell, J., \& Sayers, E. W.(2016). GenBank. Nucleic
Acids Research, 44(D1), D67-D72. https://doi.org/10.1093/nar/gkv 1276

Datta, S., Choudhary, R. G., Shamim, M., \& Dhar, V. (2011). Polymorphism in the internal transcribed spacer (ITS) region of the ribosomal DNA among different Fusarium species. Archives of Phytopathology and Plant Protection, 44(6), 558-566. https://doi.org/10.1080/03235400903187402

Dean, T. R., Kohan, M., Betancourt, D., \& Menetrez, M. Y. (2005). A simple polymerase chain reaction/restriction fragment length polymorphis $m$ as say capable of identifying medically relevant filamentous fungi. Molecular Biotechnology, 31(1), 21-27. https://doi.org/10.1385/MB:31:1:021

Diguta, C. F., Proca, I. G., Jurcoane, S., \& Matei, F. (2018). Molecular characterization by PCRRFLP of indigenous fungal isolates from hypersaline stream water in Romania. Folia Microbiologica, in press, 1-13.

Diguta, C. F., Vincent, B., Guilloux-Benatier, M., Alexandre, H., \& Rousseaux, S. (2011). PCR ITS-RFLP: A useful method for identifying filamentous fungi isolates on grapes. Food Microbiology, 28, $\quad 1145 \mathrm{e} 1154$. https://doi.org/10.1016/j.fm.2011.03.006

Duttweiler, K. B., Sun, G. Y., Batzer, J. C., Harrington, T. C., \& Gleason, M. L. (2008). An RFLP-Based Technique for Identifying Fungi in the Sooty Blotch and Flyspeck Complex on Apple. Plant Disease, 92(5), 794-799. https://doi.org/10.1094/PDIS-92-50794

Elad, Y., Baker, S. C., \& Faull, J. L. (2004). Multi trophic relationships - interaction of a biocontrol agent and a pathogen with the indigenous micro-flora on bean leaves Multi trophic relationships - interaction of a biocontrol agent and a pathogen with the indigenous micro-flora on bean leaves. Management of Plant Diseases and Arthropod Pests by BCAs, 27(January), 151154.

Endang, A., \& Farikhah, H. N. (2010). Infestation of Xystrocera festiva in Paraserianthes falcataria plantation in East Java, Indonesia. Journal of Tropical Forest Science, 22(4), 397-402.

https://doi.org/10.1007/BF01586686

Fliegerová, K., Paîoutová, S., Mrázek, J., \& Kopeân, J. (2002). Special properties of polycentric anaerobic fungus Anaeromyces mucronatus, 441-444. 
Gardes, M., \& Bruns, T. D. (1993). ITS primers with enhanced specificity for basidiomycetes, application to the identification of mycorrihiza and rusts. Molecular Ecology, 2(May 2016), 113-118. https://doi.org/Doi 10.1111/J.1365-294x.1993.Tb00005.X

Glen, M., Bougher, N. L., Francis, A. A., Nigg, S. Q., Lee, S. S., Irianto, R., ... Mohammed, C. L. (2009). Ganoderma and Amauroderma species associated with root-rot disease of Acacia mangium plantation trees in Indonesia and Malay sia. Australasian Plant Pathology, $38(4)$, https://doi.org/10.1071/AP09008 345-356.

Harsono, W. N., Rakhmawati, A., \& Prihatini, I. (2016). Isolasi dan identifikasi kapang endofit dari pohon sengon provenan kepulauan Solomon berdasarkan morfologi dan molekuler (analis a rDNA ITS (Internal Transcribed Spacer). Jurnal Biologi, 5(6), 15-27.

Hong, S. G., Liu, D., \& Pryor, B. M. (2005). Restriction mapping of the IGS region in Alternaria spp. reveals variable and conserved domains. Mycological Research, 109(1), 87-95. https ://doi.org/10.1017/S0953756204001388

Kowalski, T., \& Drozynska, K. (2011). Mycobiota in needles and shoots of Pinus nigra following Infection by Dothistroma septosporum. Phyton-Annales Rei Botanicae, 51(2), 277287.

Lawrence, D. P., Holland, L. A., Nouri, M. T., Travadon, R., Abramians, A., Michailides, T. J., \& Trouillas, F. P. (2018). Molecular phylogeny of Cytospora species as sociated with canker dis eases of fruit and nut crops in California, with the descriptions of ten new species and one new combination. IMA Fungus, 9(2), 333-370. https://doi.org/10.5598/imafungus.2018.09.02 .07

Mohammed, H. A. (2013). A PCR ITS-RFLP method for identifying fungal contamination of date palm (Phoenix dactylifera L.) tissue cultures. African Journal of Biotechnology, 12(32), 5054-5059. https://doi.org/10.5897/AJB2013.12407

Nilss on, R. H., Glöckner, F. O., Saar, I., Tedersoo, L., Kõljalg, U., Abarenkov, K., ... Picard, K. (2018). The UNITE database for molecular identification of fungi: handling dark taxa and parallel taxonomic classifications. Nucleic Acids Research, 47(D1), D259D264. https://doi.org/10.1093/nar/gky 1022
Nusaibah, S. A., Latiffah, Z., \& Hassaan, A. R. (2011). ITS-PCR-RFLP analys is of Ganoderma sp. infecting industrial crops. Pertanika Journal of Tropical Agricultural Science, 34(1), 83-91.

O’Donnell, K., Sutton, D. A., Rinaldi, M. G., Sarver, B. A. J., Balajee, S. A., Schroers, H. J., ... Geiser, D. M. (2010). Internet-acces sible DNA sequence database for identifying fusaria from human and animal infections. Journal of Clinical Microbiology, 48(10), 3708-3718.

Old, K. M., Lee, S. S., Sharma, J. K., \& Zi, Q. Y. (2000). A Manual of Diseases of Tropical Acacias in Australia, South-East Asia and India Design and production: Vlad Mosmondor. Jakarta: Center for International Forestry Research.

Palapala, V. A., Aimi, T., Inatomi, S., \& Morinaga, T. (2002). ITS-PCR-RFLP Method for Distinguishing Commercial Cultivars of Edible Mushroom, Flammulina velutipes. Journal of Food Science, 67(7), 2486-2490. https://doi.org/10.1111/j.13652621.2002.tb08763.x

Pei, N., Chen, B., \& Kress, W. J. (2017). Advances of Community-Level Plant DNA Barcoding in China. Frontiers in Plant Science, 8, 225. https://doi.org/10.3389/fpls.2017.00225

Prihatini, I., Glen, M., Wardlaw, T. J., \& Mohammed, C. L. (2015). Lophodermium pinastri and an unknown species of Teratosphaeriaceae are associated with needle cast in a Pinus radiata selection trial. Forest Pathology, 45(4), 281-289. https://doi.org/10.1111/efp.12169

Prihatini, I., Glen, M., Wardlaw, T. J., \& Mohammed, C. L. (2016). Diversity and identification of fungi as sociated with needles of Pinus radiata in Tasmania. Southern Forests, 78(1), 19-34.

Prihatini, I., Glen, M., Wardlaw, T., \& Mohammed, C. (2014). Multigene phylogenetic study of Cyclaneusma species. Forest Pathology, 44(2).

Prihatini, I., Rimbawanto, A., Puspitasari, D., \& Fauzi, D. (2018). Pengujian penanda jenis spesifik pada jamur yang berpotensi sebagai agens pengendali hayati penyakit busuk akar pada akasia. Jurnal Pemuliaan Tanaman Hutan, 12(1). https://doi.org/10.20886/jpth.2018.12.1.1-12

Puspitasari, D., Wibowo, A., Rahayu, S., Prihatini, I., Rimbawanto, A., \& No, J. A. (2016). Karakter morfologi is olat Phlebiopsis sp . 1 
jamur pengendali hayati yang potensial untuk Ganoderma philippii. Jurnal Pemuliaan Tanaman, 10(1), 51-62.

Putri, K. P., \& Bramasto, Y. (2017). Pengendalian cendawan Uromycladium tepperianum pada bibit sengon (Falcataria moluccana ( Miq .) Barneby \& J . W . Grimes ). Jurnal Perbenihan Tanaman Hutan, 5(1), 13-22.

Raeder,U., \& Broda, P. (1985). Rapid preparation of DNA from filamentous fungi. Letters in Applied Microbiology, 1(1), 17-20.

Shamim, M., Kumar, P., Kumar, R. R., Kumar, M., Kumar, R. R., \& Singh, K. N. (2017). Assessing Fungal Biodiversity Using Molecular Markers. In B. P. Singh \& V. K. Gupta (Eds.), Molecular Markers in Mycology: Diagnostics and Marker Developments (pp. 305-333). Cham: Springer International Publishing. https ://doi.org/10.1007/978-3-319-341064_15

Srivastava, S., Gupta, P. S., Lal, S., \& Sinha, O. K. (2017). Rapid identification of endophytic fungi of sugarcane (Saccharum spp. hybrid) using PCR-RFLP of rDNA. Journal of Environmental Biology, 38(1), 21-26. https://doi.org/10.3399/bjgp09X453576

Szemiako, K., Śledzińska, A., \& Krawczyk, B. (2017). A new assay based on terminal restriction fragment length polymorphis m of homocitrate synthase gene fragments for Candida species identification. Journal of Applied Genetics, 58(3), 409-414. https://doi.org/10.1007/s 13353-017-0394-5

Tigini, V., Prigione, V., Di Toro, S., Fava, F., \& Varese, G. C. (2009). Is olation and characterisation of polychlorinated biphenyl (PCB) degrading fungi from a historically contaminated soil. Microbial Cell Factories, 8(1), 5. https://doi.org/10.1186/1475-2859-85

Viaud, M., Pasquier, A., \& Brygoo, Y. (2000). Diversity of soil fungistudied by PCR-RFLP of ITS. Mycological Research, 104(9), 1027 1032. https://doi.org/10.1017/S0953756200002835

White, T. J., Bruns, T., Lee, S., \& Taylor, J. (1990). Amplification and direct sequencing offungal ribosomal RNA genes for phylogenetics. PCR protocols: A guide to methods and applications. Academic Press, Inc.

Xiang, L., Gong, S., Yang, L., Hao, J., Xue, M., Zeng, F., ... Yu, D. (2016). Biocontrol potential of endophytic fungi in medicinal plants from Wuhan Botanical Garden in China. Biological Control, 94, 47-55. https://doi.org/10.1016/j.biocon trol.2015.12.0 02

Yeh, F. C., Yang, R.-C., Boyle, T. B. J., Ye, Z.-H., \& Mao, J. X. (1999). POPGENE, the userfriendly shareware for population genetic analysis. Edmonton: Molecular Biology and Biotechnology Centre, University of Alberta, Canada.

Yuskianti, V., Glen, M., Pus pitas ari, D., Francis, A., Rimbawanto, A., Gafur, A., ... Mohammed, C. L. (2014). Species-specific PCR for rapid identification of Ganoderma philippii and Ganoderma mastoporum from Acacia mangium and Eucalyptuspellita plantations in Indonesia. Forest Pathology, 44(6), 477485. https://doi.org/10.1111/efp.12144 
J urnal Pemuliaan Tanaman Hutan

Vol. 13 No. 1, Juni 2019, p. 33 - 43 